\title{
Status and Participation of Nepali Women in Agrarian Class Structure in the Himalayan and Sub-Himalayan Region of West Bengal: An Empirical Study
}

\author{
Bhaswati Saha \\ Assistant Professor, Department of Sociology, Kalyani Mahavidyalaya, Kalyani, Dist. Nadia, West Bengal, India \\ *Corresponding author: bhaswati31saha@gmail.com
}

Received: 10-04-2020

Revised: $17-07-2020$

Accepted: 26-09-2020

\begin{abstract}
This article is comprised of a systematical analysis of 'class' and 'gender' nexus in the agrarian society. The prime focus has been given to the identification of women in the agrarian class structure. It is a systematic comparative analysis of the position and role of women in different agrarian class structure in two different zones in West Bengal. Gender relation in the agrarian class structure does not only depend on the possession of the property (i.e. land) but also related to the sexual division of labour, nature of work and intra-household relationship. Another dimension of subordination of women in the agrarian class structure is the concept of 'house-hold' which derived from a dimension of 'public-private' dichotomy. It has been discussed how the role and participation of women are expanding day by day in the agricultural sector, though they are very few recognised as an independent farmer.
\end{abstract}

Keywords: Agrarian class, Gender inequality, Private-Public dichotomy, agricultural labourer, unrecognised labour

In West Bengal, two extreme northern districts namely Darjeeling and Kalimpong are integral parts of the eastern Himalayan region. Except Siliguri Sub-division, Darjeeling district is located at the Himalayan mountain. In 2017 (14 ${ }^{\text {th }}$ February) Kalimpong was acknowledged as a $21^{\text {st }}$ district of West Bengal, before which, it was a sub-division of Darjeeling district. Both the 'terai' and 'duars' region of North Bengal to the elevation of 3636 $\mathrm{m}$ on the outer Himalaya, have been broadly identified as the sub-Himalayan region of west Bengal. The present study intends to analyse empirically what is actual position of Nepali women in different agrarian class structure and their participation in the agriculture according to their class status particularly in the context of Himalayan (hills) region of Kalimpong district and
sub-Himalayan regions (terai) of Darjeeling district of West Bengal which reclines in Eastern Himalayan range.

It is impossible to understand the nature and dynamics of agrarian rural society without a clear notion of its class structure. Position and role of women in the agriculture is in effect dominated by its different agrarian class structure and also varies from one region to another.

First of all, in this paper an attempt has been made to understand from both conceptual and empirical frame of references that what is actual class position of women in the agrarian structure of the Himalayan and

How to cite this article: Saha, B. (2020). Status and Participation of Nepali Women in Agrarian Class Structure in the Himalayan and Sub-Himalayan Region of West Bengal: An Empirical Study. Int. J. Soc. Sci., 9(03): 133-140. 
Sub-Himalayan region of West Bengal. Secondly this paper presents a wide range of agricultural activities performed and responsibilities undertaken by the women agriculturalists from different kind of agrarian classes for the whole year.

\section{A Note on Study Area and Methodology}

Before detailed discussion, a clear and brief introduction about study area and methods are necessary. For this study Bongkhasmahal village of Kalimpong I block from Kalimpong district was selected for representation of Himalayan region and Siubar village under Maniram Gram Panchayat of Naxalbari block from Siliguri Sub division of Darjeeling district represented here subHimalayan region of West Bengal.

As the present study is about the Nepali women farmers, so villages were selected purposefully. Empirical data have been collected from the respondents by doing faceto-face interview during fieldwork. Multi-stage (four stages) sampling has been used to select the respondents. Firstly, blocks were selected from Darjeeling district; secondly, selection of Gram Panchayats from the selected/sampled blocks; thirdly, selection of villages from those Gram Panchayats; and finally, the required number of respondents (women farmers) are selected from those sampled/selected villages. After selecting the research area/field, fieldwork was conducted into two phases. The first phase of the field work was census survey carried out to know the detailed socio-economic aspects of the sampled villages and villagers. The second phase of the survey was sample survey. From the hill region 150 respondents were selected and from the SubHimalayan region 135 respondents were selected.

\section{Agrarian Class as Theoretical Conceptualisation}

Social class is one of the important types of social stratification and classes are related to one another in terms of inequality or hierarchy. Social class is generally defined as a stratum of people occupying the similar social position in terms of wealth, income, occupation and factors like education. Generally 'class' is related to economic differences.

Karl Marx has given a very popular definition of class.
According to him, class is an aggregate of people who have same position in the mode of production. He rejected other criteria for defining class like occupation, education, income etc. Max Weber gives a different view of a class. He has given the idea of the life chances and market provides the life chances. Again, sociologist Andre Beteille has emphasized on a number of factors like economic, social and political for explaining class.

Theoretically, agrarian structure has been analysed by various imminent sociologists, economists like Eric Wolf and Hamza Alavi, A.R. Desai, Yogendra Singh, K.L Sharma, Ramkrishna Mukherjee, Sir Daniel Thorner and D.N. Dhanagre. These social scientists have given the most important models of Agrarian Class Structure. Model of 'Malik', 'Kisan' and 'Mazdoor' of agrarian class was summarised by Sir Daniel Thorner after analysing a diverse peasant population and land holding pattern of Indian rural society. Concept of 'Middle Peasantry' and its significance came out from the theories of Eric Wolf and Hamza Alvi.

Dhanagare's model is an extension of Daniel Thorner's model and was influenced by Mao Tshe Tung. He mentioned five classes like landlords, rich peasants, middle peasant, poor peasant and landless lobourers. There is no uniform definition and type of class structure and it also varied from one region to another. In the Himalayan and sub-Himalayan region have it's own agrarian history

During the post reform period, agrarian structure of Darjeeling hill is composed of broadly two categories of people on the basis of land ownership. These are: (i) Pattadar or Malik who have their own land and ii) Ketala or Agricultural labour who do not own land. They cultivate other's land on the basis of daily wage or contract basis. Between these two categories there is another category of people who are known as share-croppers (Pakurey). But practically no clear cut distinction can be made. All classes are interlinked with each other. Swatasiddha Sarkar (2010) included four categories of agricultural population i.e. non-cultivating owners, cultivators, cultivators cum adhiwals, or even partly khetala in the Pattader category. He also said that "it is not feasible that a pattadar could become a 
Status and Participation of Nepali Women in Agrarian Class Structure in the Himalayan and Sub-Himalayan Region of West Bengal $\mathbb{J}_{\text {SRA }}$

pakurey at the same time in the same village. However, a pattadar of a village could be a pakurey of a nearby village and vice-versa." Again he has included landless agricultural labour and bargadars in the pakurey category. He has identified two types of pakurey. One is cultivating pakurey and another is non-cultivating pakurey. Cultivating pakurey cultivates pattadar's land and non-cultivating pakurey do not cultivate any one's land, they only employed as a daily wage labourer in the Malik's house. He has provided a distinct division between adhiwal, malik and pakurey. When landowning people keep themselves in sharecropping in the other's land then they are known as adhiwals. Again when these land owning people lease out agricultural lands to others then they are known as maliks. Pakureys are those people who do not possess land and engaged themselves in share-cropping. Prof. Buddhadeb Chaudhuri has discussed different types of agrarian classes in his article "Agrarian relations in a hill region" to find a proper idea about different types of agrarian relations and various type of terms and conditions of these relations. He has classified agrarian classes by following ways ${ }^{1}$ :

\section{Landowner or Malik:}

(i) absentee landowner

(ii) Non-cultivating landowner

(iii) Cultivating landowner

(a) Performs agricultural operations

(b) Supervises agricultural operations

(iv) Cultivating landowner cum sharecropper/ agricultural labourer

\section{Share-cropper or Pakhurey:}

(i) Share-cropper

(ii) Share-cropper cum landowner

(iii) Share-cropper cum agricultural labourer

\footnotetext{
${ }^{1}$ Chaube, S.K (ed). 1985: The Himalayas Profiles of Modernisation and Adaptation, Sterling Publishers Private Limited, New Delhi, page 99.
}

Agricultural labourer or Khetala:

i) Labourer

ii) Labourer cum landowner

iii) Labourer cum share-cropper

\section{Women in the Agrarian Class Structure}

In agrarian social structure, land is the primary criteria to make unequal relation consequently the formation of class among people. Land is not only important dimension for the formation of economic hierarchy in the agrarian class structure but it is a symbol of social and cultural prestige for the farmers. The agrarian social structure can be classified broadly into two classes: (i) the landowners and (ii) the landless. It is not as simple as it has been defined because of the variation of land ownership in the rural social structure. In rural society, some landowner possesses a large amount of land and while others have a small amount of land. There is a category in between the landowner and landless. This class is known as share-croppers. Landless people earn money from land as sharecroppers and agricultural labourers.

Now the position of women farmers has to be analyzed both from the perspective of agrarian class and gender. As dual-system of theory or socialist feminism identified 'class' as an economic position of a group and it also concerns with the exploitation of women's work within the patriarchal structure of society. The position of women is affected by not only their 'class' position but also production, reproduction, socialization pattern and sexuality.

This study is concerned with the women in the agrarian class structure. In the above discussion, class has been broadly divided into two categories: (i) the person who has land and (ii) who do not have land. Here word 'person' indicates both male and female. But in the patriarchal society, ownership of land is mainly vested on male line which creates a problem between women and agrarian class structure. There is no individual identity of a woman in the agrarian class structure in spite of having own land by their names. Women farmers are identified and classified as their male counterparts. Society has not yet properly recognised 
women as independent farmers. During the survey, it has been noticed that people are more habituated and interested in uttering the name of the landowning farmers or kuddars who are male, while they almost never mentioned women as landowning farmers or $k u d o s$. Here women are recognized only in some cases i.e. in the single-family structure and when the widow is the head of the family, in the case of divorcee women, and separated women. But here, to some extent, women have been identified as agricultural labourers. Gender relation in the agrarian society is more complex than from the industrial society. Class status of women in industrial society is much clearer because they are paid workers. In agrarian society, women are paid workers only when they incline to agricultural labour category. Gender relation in the agrarian class structure does not only depend on possession of property (i.e. land) but also related to the sexual division of labour, nature of work and intra-household relationship. Regarding sexual division of labour, ploughing is the most important activities in the field of agricultural activities which is predominantly controlled by the male counterparts. It is not culturally sanctioned for the women. Apart from ploughing all of the other activities are performed by the female folk. Women of agrarian society perform all types of agricultural tasks from pre-sowing to post-harvesting activities including different types of household works, reproduction and also childcare. Unfortunately, under the socio-cultural construction, all these works are unpaid, undervalued, invisible and not recognized by society. Undervaluation of the female workforce is one of the important additions for subjugation of women in the agrarian class structure. For the present study, women's activities in agricultural operations has been classified into four categories:

(a) Landless agricultural labourers.

(b) Women cultivating their family land and also working as (agricultural) wage labourers.

(c) Women working in their own family land or are engaged as exchange labour on others land due to the dearth of labourers or save the labour charge.

(d) Women supervising the agricultural operations performed by the labourers.
Here all types of works category (except agricultural wage labour) are considered as 'domestic mode of production'. Women workforce is determined by the conjugal and kinship relationship with zero market values and free of cost. Gender relationship is often believed that private sphere is inferior to public sphere under theoretical framework of the structuralism. Another dimension of subordination of women in the agrarian class structure is the concept of 'household' which derived from a dimension of 'publicprivate' dichotomy. The household is the primary unit in agrarian society for production, reproduction, consumption and socialization also. Composition and function of the household have direct effect on the lives of women. Property relation, position in the mode of production, participation in the economic activities, access to labour and income etc are directly affected by the intra-household relations. The women workforce in farming generally is not considered as a separate agrarian class due to: firstly, the absence of direct linkage or close connectivity with land (ownership), has been discussed in para; secondly, the patriarchal concept of the 'household' and thirdly, the invisibility of the nature of work they are involved into.

The land ownership of women in the study area is very low. Among 135 respondents in Sub Himalayan region (Suibar village), only 25 respondents (18.51\%) have right on land or they have their own land. One respondent among these 25 landowner women had sold her land. Consequently only $24(17.77 \%)$ respondent women out of 135 are landowners. 7 women out of these landowning women are absentee landowners as they have left their natal village after their marriage. So, presently there are 17 women in the village who own land. But all of them do not cultivate their land as 5 respondents have given their land to Adhiars for share-cropping. Respondents have been classified below according to their membership in the agrarian class structure linked to land and contractual obligations if any (e.g. tenancy, produce of land and labour):

From the above table 1 it is clear that in the Himalayan Region (Bongkhasmahal village), the majority of the respondents belong to land owning cultivator classes, followed by pakurey cum agricultural labour, land owning 
Status and Participation of Nepali Women in Agrarian Class Structure in the Himalayan and Sub-Himalayan Region of West Bengal $\mathbb{J}_{\text {S }}$

Table 1: Distribution of the Respondents on the Basis of the different Agrarian Classes

\begin{tabular}{|c|c|c|}
\hline \multirow{2}{*}{ Agrarian Classes } & No of Respondents (\%) & No of Respondents (\%) \\
\hline & Bongkhasmahal & Suibar \\
\hline Only Land owning Cultivators & $49(32.7)$ & $12(8.9)$ \\
\hline Land owning Cultivators cum Adhiwal ${ }^{2}$ & $26(17.3)$ & $50(37.0)$ \\
\hline Pakurey $^{3}$ / sharecropper cum agricultural Labour & $35(24.0)$ & 20() \\
\hline Land owning Cultivators cum Adhia cum Agricultural Labour & $19(12.7)$ & $28(14.8)$ \\
\hline Only Agricultural Labour & $20(13.3)$ & $15(11.1)$ \\
\hline Total No & $150(100.0)$ & $135(100.0)$ \\
\hline
\end{tabular}

Source: Field Survey.

Table 2: Comparative Distribution of Respondent's Family on the Basis of the Land Holding Pattern and Their Castes

\begin{tabular}{|c|c|c|c|c|c|c|c|c|c|c|}
\hline \multirow{3}{*}{ Landholding Caste } & \multicolumn{10}{|c|}{ No of Respondents (\%) } \\
\hline & \multicolumn{5}{|c|}{ Bong Khasmahal } & \multicolumn{5}{|c|}{ Siubar } \\
\hline & GEN & SC & ST & OBC & Total & GEN & SC & ST & OBC & Total \\
\hline Landless & $30(20.0)$ & $2(1.33)$ & $19(12.66)$ & $4(2.66)$ & $55(36.66)$ & $9(6.66)$ & $8(5.92)$ & $16(11.85)$ & $2(1.48)$ & $35(25.90)$ \\
\hline Marginal ( 0-2.5 acre) & $34(22.6)$ & $18(12.0)$ & $5(3.33)$ & $2(1.33)$ & $49(32.66)$ & $3(2.22)$ & $73(54.07)$ & $6(4.44)$ & $2(1.48)$ & $84(62.22)$ \\
\hline Small (2.5-5 acre) & $20(13.3)$ & $10(6.66)$ & $3(2.0)$ & $2(1.33)$ & $35(23.33)$ & $4(2.96)$ & $7(5.18)$ & $4(2.96)$ & $1(0.74)$ & $16(11.85)$ \\
\hline Middle (5-10 acre) & $5(3.33)$ & $4(2.66)$ & 0 & $2(1.33)$ & $11(7.33)$ & 0 & 0 & 0 & 0 & 0 \\
\hline Large (above 10 acre) & 0 & 0 & 0 & 0 & 0 & 0 & 0 & 0 & 0 & 0 \\
\hline Total & $89(59.33)$ & $34(22.66)$ & 17 (11.33) & $10(6.66)$ & $150(100.0)$ & $16(11.85)$ & $88(65.18)$ & $26(19.25)$ & $5(3.70)$ & $135(100.0)$ \\
\hline
\end{tabular}

Source: Field Survey.

cultivators cum adhiwals then land owning cultivators cum adhiwals cum agricultural labour and lastly the agricultural labourer class. Here it should be noted that in hill villages no respondents come from 'large peasant families'. Land owning families can be sub-categoriesd as 'marginal' peasant, 'small' peasant and 'middle' peasant (Table 2). In the SubHimalayan village most of the respondents belong to the landowning cultivators cum adhiwals, followed by Land owning Cultivators cum Adhiwals cum Agricultural Labour because of most of the respondents are from 'marginal' and 'small' peasant families. Their land is not enough for maintenance livelihood of family for whole year. So peasants of marginal land holding families often go for adhia system or share-cropping system and engaged

\footnotetext{
${ }^{2}$ Here Adhiwals means land-owning family act as sharecropper in the other's land.

${ }^{3}$ Pakuray are those people who do not possess land and engaged themselves in share-cropping in hill region.

${ }^{4}$ Marginal (0-2.5 acre), Small (2.6-5 acre), Middle (5.1-10 acre), Large (above 10 acre).
}

as an agricultural labour in peak season. In this village only land owning families are small (only 9\%). In the sub-Himalayan region It was found that respondents of the landowning cultivator's and adhiwal families have more workload in agricultural activities than who are only agricultural labourers especially during the postharvesting period and processing of food and seeds. They keep sometimes in a day or in a week for storing, drying in the sunshine, observation etc. And they shoulder this workload as a part of household work. The landless agricultural labourer (not adhiwals), worked other's land for definite activity and definite time. They are also paid for work. Actually, their primary source of income is nonagricultural works. Respondents of the rich landowning families save their physical energy by engaging employed hired labourers. They then supervise the hired labourers. But respondents of the adhiya families or marginal families or small landholding families cannot afford such labourers. They mainly depend on parma system. In the adhiwal families, respondents are more 
exploited than landowning families. Adhiya families provide free labour for their family production and production is ultimately controlled by the landowners. In the hillly areas, agreement (written or formal) between pakurey and landowners is not in existence. They make agreement orally or informally. Many pakurey families give free labour to their landlord.

In the plain village, the picture is not same. Formal agreements are made between land-owner and adhiyar. After production adhiyar gives fifty percent of the production to the landowner according to contact. They do not provide any extra labour to the land owning families. So respondents of the hill village from the pakurey families are more exploited than the plain village.

\section{Major Farm and Off-farm Roles of Rural Women}

In general, following are the major farm and off-farm roles performed by women both in hill and plain villages.

\section{Pre-sowing and sowing role/s}

* To clean and prepare the field/s during premonsoon period

* Preparation of compost and cow dung manure

* To carry composed manure and seeds to the field

* Leveling of the land

- Preparation of the seed-bed (for paddy cultivation)

* Proper observation of the seed bed

* Sowing of seeds

* Maintenance of agricultural implements

* Selection and treatment of seeds including hulling

* Transplantation

* Raising maize/vegetable/ginger/chilly and other nursery products

\section{Inter-cultivation role/s}

* Irrigation

* Separation of new ginger plants from mother ginger (only for ginger cultivation)

* Weeding
* 'Gorai'/earthling for maize

* Preparation and application of organic fertilizer/ manuring

* To take care of plants

* Watching standing crops

* To get knowledge about plant diseases, pruning, staking, water management

\section{Harvest and post-harvest role/s}

* Reaping of crops

* Collecting of crops

* Threshing ( in hill area threshing is done by male persons)

* Winnowing drying and cleaning of grains

* Stacking the straw (for paddy)

* Sieving

* Storing and treating of grain and seeds

\section{Allied agriculture role/s}

* Cleaning of cattle shed/s

* Provide food for cattle (feeding) and grazing

* Breeding

* Milking

* Store cow dung for fuel and manure

* Taking care of sick cattle

* Getting and storing cattle feed and dairy equipments

* Kitchen gardening

* Taking care of Poultry farm, piggery

* Collecting eggs

* Cooking food for farm labourers

* Supervision of farm work/s

* Discussion with other farmers/specialists about agriculture /allied agriculture operations

* Evaluation of printed materials / listening to radio for farm / allied farm information

* Collect crops and vegetables and weighing and bagging 
* Help in loading crops on the vans (primarily this work is done by males)

* Marketing eggs, milk, chicken, pig, orchid, flower, vegetables, fruits etc. ( for the hill)

Involvement of women in the decision-making process is one of the essential indicators of defining status and development not only in the household level but also in societal level. In both hill and plain areas, women members of agricultural labour families or 'pakurey' do not take any decision regarding the issues like use and purchase of machines, seeds, fertilizers, pesticides, mode of labour engagement etc. In plains very often they purchase machines for providing on rent. Family members jointly discuss the issues. Women cannot take any decision related to the issues like land and its' utilization. Among the agrarian labour sections, it has been observed that decisions regarding participation of female members of the family as agricultural labourers is taken by women themselves whether they will work as agricultural labourer or not or they will go outside of their villages or not. But in some cases, women from relatively advanced families and from upper castes in the hill village do not solely decide regarding this issue. For 'Kud' (in hill) and 'Adhiyar' (in plain) families selection of land, land utilization and crop selections they jointly take decision.

Land owning families while giving land to the Adhiar require to take several important decisions related to allotment of lands to the 'adhiar', the tenure of the same etc are taken by male members of family. Male members of land-owning families decide various aspects on sharing the land i.e. different terms and conditions of contact including the area and plot of the land, type of crops to be yield, to whom land is to be given under 'Adhiyari' system. Even in the absence of male members of the family, they enjoy the authority by directing female members through telephones and others means of communications or they usually settle these issues before leaving their home. Women members of the 'Adhiyar' family do not solely decide issues like whose land to be cultivated, which land to be cultivated, which crops to be grown etc. Participation of women in landowning families in major decision-making process in farm related issues like purchase and sell of land, investment in farming, land utilization for agriculture or selection of land for farming, procurement of credit from bank etc are relatively low in both hill and plain. But through SHGs women are playing active role in procurement of credit. In hill village it is found that what type of cropping has to be cultivated (like cardamom, orange, or grass for animal husbandry) are decided by male members. But when women are members of the SHGs then they decide whether floriculture or Goatry or piggery can be done or not. In hills many women from land owning families take decision related to controlling of labour, savings and investment of money in agriculture, business and other family requirements.

\section{CONCLUSION}

Gender relation in the agrarian society is undervalued and complex. Society has not yet properly recognised women as independent farmers. In spite of that women's position in agrarian classes have been changing for few decades before, especially after implementation of the Hindu Succession (Amendment) Act, 2005, as nature of land right is a very important dimension for class formation in agrarian society. It can be stated that land reform program, population growth, economic liberalization, trained labour migration, communication, modernization, adoption of consumerist culture, new technology, individualistic attitude has brought about several changes in gender relationship, familial relationship and the overall network of agrarian social relationship in rural peasant society. On the contrary the role and participation of women are expanding day by day in agricultural sector because men are engaged in other sectors of the economy and their out-ward migration has become a prominent feature on account of lack of prospect in agriculture.

\section{REFERENCES}

Abbott, Pamela. Claire Wallace and others. 2008. An Introduction to Sociology Feminist Perspectives. Routledge, London and New York.

Banerji, A.K. et al. 1980. West Bengal District Gazetteers - Darjiling. Calcutta: Dr. Barun De, Honorary State Editor, West Bengal District Gzettee.

Bardhan, Pranab K. 1984. Land, Labour and Rural Poverty: Essays in Development Economics. Oxford University Press, Delhi. 
Basu, Pradip. 1998. Nakshalbarir Purbokhon: Kichu Post Modern Vabna. Progressive Publishers, Kolkata.

Beteille, Andre. 1974. Studies in Agrarian Social Structure. Oxford University Press, Delhi.

Chaube, S.K (ed) 1985. The Himalayas Profiles of Modernisation and Adaptation. Sterling Publishers Private Limited, New Delhi.

Chauhury, Samhita and Manojit Dasgupta. 2016. A Comprehensive District Profile of Darjeeling. N.L Publishers, Siliguri.

Dasai, Mamata. 2004. Darjeeling the Queen of the Hills GeoEnvironmental Perception. K.P Bagchi \& Company, Kolkata.

Dasgupta, Anirban. 2006. Agrarian reforms in West Bengal since 1977. Abridged om-line version Phd Dissertation, University of California.

Dasgupta, Biplab. 1984. Sharecropping in West Bengal: From Independence to Operation Bargal. Economic and Political Weekly, 19(26): A85-A87+A89-A96.

Dasgupta, M. and Samad, A. 1980. Nepali's Land Revenue System and Demographic Changes in the Darjeeling Hill Area. North Bengal University Review, Humanities and Social Sciences, 1(1): 69-77.

Dasgupta, Manas. 2004. Udarikaran, Unnayan o Uttarbanga. Boiwala, Kolkata.

Dhamala, Ranju R. (ed) 1993. Problems and Strategies of Development in the Eastern Himalaya. Gyan Publishing House, New Delhi Jackson, Stevi and Jackie Jones (ed.) (1998) Contemporary Feminist Theories. New York University Press, Washington Square, New York.

Krishanji, N. 1980. Agrarian Structure and Family Formation: A Tentative Hypothesis. Economic and Political Weekly, 15(13): A38-A43.

Kundu et al. 2013. Role of SHGs: A case study of Bardhman district of West Bengal, International Journal of Social Science, 2(1): 63-72.
Mitra, Amit. 1988. Agrarian Relations in Pre-colonial North Bengal. Occational paper II, $19^{\text {th }}$ March, 1988, Central for Social Studies, Surat.

Mukherjee, Ramkrishna. 1981. Realities of Agrarian Relations in India. Economic and Political Weekly, 16(4): 109-116.

Pai, Sudha. 1987. Class, Gender and Agrarian Change: An Analysis of the Status of Female Agricultural Labour in India. Social Scientist, 15(6): 16-32.

Patnaik, Utsa. 1983. On the Evolution of the Class of Agricultural Labourers in India. Social Scientist, 11(7): 3-24.

Roy, Choudhury Tapash K. 1987. Land Control: Class Structure and Class Relations in Western Duars (1871-1905). Journal of Asiatic Society of Bangladesh, XXXII (01), special Issue.

Saha, Satyajit. 2019. Employment Generation and Asset Creation through MGNREGS: A Study of Harirampur Block of Dakshin Dinajpur District, West Bengal. International Journal of Social Sciences, 8(3).

Saha, Gour Krishna. 2012. North Bengal and North East India-A Transitional Perspective. N.L. Publishers, Shiv Mandir, Siliguri, Darjeeling: Pashimbanga.

Saradamoni, K. 1991. Filling the Rice Bowl: Women in the Paddy Cultivation. Sangam Books (India) Private Limited, Hydrabad.

Sarkar, Swatahsiddha. 2013. Agrarian Reforms and the Precarious State of Affairs in the Darjeeling Hills: A Review. In: K. Suman Chandra et al. (ed.) Agrarian Crisis in India, $1^{\text {st }}$ edn Academic Foundation, New Delhi.

Somasekhar, K. 2015. Financial Inclusion Through Self-help Groups for Rural Livelihoods - An Analysis. International Journal of Social Science, 4(4): 289-296.

Subba, Tanka B. 1989. Dynamics of a Hill Society: The Nepalis in Darjeeling and Sikkim Himalayas. Mittal Publications, Delhi. 